Assiut University web-site: $\underline{w w w . a u n} . e d u . e g$

\title{
THE RELATIONSHIPS BETWEEN RUMINAL JUICE, URINE, SERUM AND FECAL ZINC IN EXPERIMENTALLY ZINC DEFICIENT OSSIMI LAMBS
}

\author{
ABDELGHANY HEFNAWY ${ }^{1}$, MAHMOUD ATEF YOUSSEF HELAL ${ }^{1}$, IBRAHIM SABRY ${ }^{1}$ and \\ YASSEN ABDELRAOOF ${ }^{1}$ \\ ${ }^{1}$ Department of Animal Medicine, Faculty of Veterinary Medicine, Benha University, 13736 Moshtohor - Egypt
}

Received: 18 February 2018; Accepted: 21 March 2018

\begin{abstract}
This study was conducted to evaluate the relationships between ruminal juice, urine, serum and fecal Zinc (Zn) concentrations in experimentally $\mathrm{Zn}$ deficient lambs. Fifteen lambs with average age 5-6 months and body weight $28-30 \mathrm{~kg}$ were divided into two groups, first group (10 lambs) for induction of $\mathrm{Zn}$ deficiency and the second group (5 lambs) as control one. Ruminal juice, urine, serum and fecal samples were collected every two weeks until 12 weeks for measuring of $\mathrm{Zn}$. The results revealed that alopecia, skin abnormalities, loss of appetite and emaciation were shown in experimentally induced $\mathrm{Zn}$ deficient lambs from the $6^{\text {th }}$ week. Serum, ruminal juice, fecal and urine $\mathrm{Zn}$ concentrations were significantly decreased $(\mathrm{p}<0.05)$ in the experimentally induced $\mathrm{Zn}$ deficient lambs from the $8^{\text {th }}, 10^{\text {th }}, 6^{\text {th }}$ and $8^{\text {th }}$ week respectively than that of the control one. Significant $(\mathrm{p}<0.05)$ decrease in ALP and SOD were detected in $\mathrm{Zn}$ deficient lambs than that of control one. Significant $(\mathrm{p}<0.05-0.01)$ positive correlations between serum $\mathrm{Zn}$ and urine, ruminal juice and fecal $\mathrm{Zn}$ were detected. There was significant positive correlation between ruminal juice and urine $\mathrm{Zn}$. There was significant $(\mathrm{p}<0.01)$ positive correlation between urine and fecal $\mathrm{Zn}$. Evaluation of $\mathrm{Zn}$ concentrations in different body fluids rather than blood serum can be used as diagnostic tool for diagnosis of Zn deficiency in lambs. Fecal Zn concentration can be used as a biomarker for early diagnosis of Zn deficiency in lambs.
\end{abstract}

Key words: Zinc, deficiency, Relationships, Lambs

\section{INTRODUCTION}

Zinc $(\mathrm{Zn})$ is an essential trace element and many physiological processes are impaired if it is not supplied in sufficient quantities in the diet. $\mathrm{Zn}$ is a component of many metalloenzyme such as copper$\mathrm{Zn}$ superoxide dismutase ( $\mathrm{Cu}-\mathrm{Zn} \mathrm{SOD})$, carbonic anhydrase, alcohol dehydrogenase, carboxypeptidase, alkaline phosphatase and RNA polymerase, which affect on the metabolism of carbohydrate, proteins, lipids and nucleic acid, also $\mathrm{Zn}$ has an influence on immune system (NRC, 1985; Shankar and Prasad, 1998) as well as is a component of thymulin (a hormone produced by thymic cells that regulates cellmediated immunity). The animals deficient in $\mathrm{Zn}$ exhibit atrophy of the thymolymphatic system, depressed cell-mediated immunity and increased to infection. Secondary Zn deficiency may be caused by several factors such as the consumption of immature grasses which affects digestibility, the feeding of latecut hay which may be poorly digestible and the

Corresponding author: Dr. ABDELGHANY HEFNAWY E-mail address: abdelghany hefnawy @yahoo.com

Present address: Department of Animal Medicine, Faculty of Veterinary Medicine, Benha University, 13736 Moshtohor - Egypt. presence of excessive dietary sulfur (Radostits et al., 2000). High $\mathrm{Ca}$ content of the diet raised the $\mathrm{Zn}$ requirement and reduces $\mathrm{Zn}$ absorption (Miller, 1967). Plasma, urinary, and hair $\mathrm{Zn}$ are reliable biomarkers of $\mathrm{Zn}$ status (Lowe et al., 2009). In this study, we try to use body fluids rather than blood such as, feces, urine and ruminal juice and their relationships for determination of its $\mathrm{Zn}$ contents as a trial for early diagnosis of $\mathrm{Zn}$ deficiency in sheep.

\section{MATERIALS AND METHODS}

Fifteen female, six-months-old Ossimi lambs with an average live weight of $30.45 \pm 1.2 \mathrm{~kg}$. $\mathrm{kg}$ in a private farm in Kaliobia governorate were used. Lambs were classified into two groups, the first group as control one $(\mathrm{N}=5)$ and the second group for experimental induction of $\mathrm{Zn}$ deficiency $(\mathrm{N}=10)$. Fecal examination, liver function, and kidney function tests were carried out for detection of any internal parasite or any liver and kidney affections that occur for animals after exposure to systemic anthelmentic (Ivermectine + clorsulon $0.2 \mathrm{mg} / \mathrm{kg}$ body weight $\mathrm{s} / \mathrm{c}$ ) 2 doses by 2 weeks intervals before induction of $\mathrm{Zn}$ deficiency. $\mathrm{Zn}$ deficiency was induced by 
feeding of lambs on high calcium corn soya bean meal diet by increasing the calcium and phosphorus level in the ration (Miller, 1967) by addition of ground limestone and steamed bone meal. Composition and analysis of the experimental and control ration as shown in table (1). Distilled water was offered ad libtium.

Blood samples were collected from jugular vein. The samples were allowed to clot in slanting position at room temperature for about 2 hours then the samples were centrifuged at $3000 \mathrm{rpm}$ for 10 minutes, the clear sera were aspirated carefully by automatic pipette and transferred into clear dry labeled Eppendorf tubes and stored at $-20 \circ \mathrm{C}$ till analysis. Only clear non-hemolyzed sera were used for the biochemical determination of $\mathrm{Zn}$, alkaline phosphatase (AP) and superoxide dismutase (SOD).

Serum, fecal, urine and ruminal juice samples were collected at 2 weeks intervals until clinical signs of $\mathrm{Zn}$ deficiency were appeared.

Zn levels were detected by using Atomic Absorption Spectrophotometer (AAS) according to Fuwa et al. (1964). AP was measured by using of the special kits according to REC. GSCC (DGKC) (1972) while SOD was measured by method according to Nishikimi et al. (1972).

\section{STATISTICAL ANALYSIS}

The obtained results from the experiments were expressed as mean \pm SEM and were analyzed by analysis of variance (ANOVA) for repeated measures with means tested for significance by Duncan's multiple range tests. The correlations between the obtained results were tested with a Pearson correlation test. Differences were declared significant at $\mathrm{P}<0.05$. SAS (2005) software was used to conduct this analysis.

\section{RESULTS}

\section{Clinical parameters:}

Comparing with control lambs, experimentally $\mathrm{Zn}$ deficient lambs showed paleness of mucus membranes, decreased ruminal movements, as well as increased respiratory and pulse rates from the $6^{\text {th }}$. week of the experiment. Loss of appetite, emaciation, alopecia and wool loss in different body regions of experimentally $\mathrm{Zn}$ deficient lambs. Skin abnormalities (rough skin, thickened, cracked, wrinkled with dandruff) were also observed.

\section{Biochemical parameters:}

There were significant $(\mathrm{p}<0.05)$ decrease in $\mathrm{Zn}$ concentrations in the feces, serum, urine and ruminal juice samples from the $6^{\text {th }}, 8^{\text {th }} ., 8^{\text {th }}$, and $10^{\text {th }}$. weeks respectively after inductions of $\mathrm{Zn}$ deficiency than that of control lambs (table 2). AP and superoxide dismutase were significantly decreased from the $10^{\text {th }}$. week in $\mathrm{Zn}$ deficient lambs than that of control ones (table 3).

There were significant positive correlations between serum $\mathrm{Zn}$ and urine $(\mathrm{p}<0.05)$, ruminal juice $(\mathrm{p}<$ $0.01)$ and fecal $\mathrm{Zn}(\mathrm{p}<0.01)$. There was significant $(\mathrm{p}<0.01)$ positive correlation between ruminal juice and urine $\mathrm{Zn}$ as well as there was significant $(\mathrm{p}<$ $0.05)$ positive correlation between urine and fecal $\mathrm{Zn}$ (table 4).

Table 1: Dietary supplementation and composition of control and $\mathrm{Zn}$ deficient lambs (kg/head/day)

\begin{tabular}{|c|c|c|c|c|c|c|c|}
\hline \multicolumn{3}{|c|}{ Elements (kg/head/day) } & \multicolumn{4}{|c|}{ Composition } & \\
\hline $\begin{array}{c}\text { Alfa alfa } \\
\text { hay }\end{array}$ & $\begin{array}{c}\text { Protein } \\
\text { supplement }\end{array}$ & Grains & $\mathrm{Ca}$ & $\mathrm{P}$ & $\mathrm{CP}$ & TDN & $\mathrm{Zn}$ \\
\hline \multirow{2}{*}{0.2} & \multirow{2}{*}{0.25} & \multirow{2}{*}{0.52} & Control $0.84 \%$ & Control $0.45 \%$ & $17 \%$ & $73 \%$ & $35 \mathrm{ppm}$ \\
\hline & & & Zn deficient $1.7 \%$ & Zn deficient $0.9 \%$ & & & \\
\hline
\end{tabular}


Table 2: Serum, urine, fecal, and ruminal juice zinc (ppm) levels in control and experimentally induced $\mathrm{Zn}$ deficient lambs.

\begin{tabular}{|c|c|c|c|c|c|c|c|c|}
\hline \multirow{2}{*}{ Time } & \multicolumn{2}{|c|}{ Serum } & \multicolumn{2}{|c|}{ Urine } & \multicolumn{2}{|c|}{ Feces } & \multicolumn{2}{|c|}{ Ruminal juice } \\
\hline & Control & $\begin{array}{c}\text { Zn deficient } \\
\text { lambs }\end{array}$ & Control & $\begin{array}{l}\text { Zn deficient } \\
\text { lambs }\end{array}$ & Control & $\begin{array}{c}\text { Zn deficient } \\
\text { lambs }\end{array}$ & Control & $\begin{array}{c}\mathrm{Zn} \text { deficient } \\
\text { lambs }\end{array}$ \\
\hline 0 - days & $2.39 \pm 0.04$ & $2.39 \pm 0.06$ & $0.28 \pm 0.01$ & $0.29 \pm 0.005$ & $0.57 \pm 0.04$ & $0.60 \pm 0.03$ & $1.80 \pm 0.17$ & $1.71 \pm 0.21$ \\
\hline 2 weeks & $2.33 \pm 0.03$ & $2.30 \pm 0.06$ & $0.29 \pm 0.001$ & $0.27 \pm 0.009$ & $0.55 \pm 0.02$ & $0.57 \pm 0.02$ & $1.81 \pm 0.27$ & $1.56 \pm 0.24$ \\
\hline 4 weeks & $2.42 \pm 0.01$ & $2.40 \pm 0.08$ & $0.25 \pm 0.002$ & $0.26 \pm 0.004$ & $0.43 \pm 0.02$ & $0.48 \pm 0.02$ & $1.69 \pm 0.1$ & $1.62 \pm 0.11$ \\
\hline 6 weeks & $2.34 \pm 0.04$ & $2.16 \pm 0.1$ & $0.28 \pm 0.01$ & $0.24 \pm 0.005$ & $0.49 \pm 0.02$ & $0.31 \pm 0.03 *$ & $1.36 \pm 0.1$ & $1.39 \pm 0.13$ \\
\hline 8 weeks & $2.35 \pm 0.06$ & $1.87 \pm 0.2 *$ & $0.25 \pm 0.001$ & $0.17 \pm 0.009^{*}$ & $0.44 \pm 0.06$ & $0.26 \pm 0.02 * *$ & $1.16 \pm 0.1$ & $1.07 \pm 0.11$ \\
\hline 10 weeks & $2.51 \pm 0.05$ & $1.43 \pm 0.07 *$ & $0.27 \pm 0.02$ & $0.17 \pm 0.007 *$ & $0.54 \pm 0.03$ & $0.21 \pm 0.01 * *$ & $1.26 \pm 0.1$ & $0.77 \pm 0.12 *$ \\
\hline 12 weeks & $2.41 \pm 0.05$ & $1.09 \pm 0.04 * *$ & $0.28 \pm 0.02$ & $0.13 \pm 0.007 * *$ & $0.55 \pm 0.01$ & $0.18 \pm 0.01 * *$ & $1.40 \pm 0.16$ & $0.64 \pm 0.14 *$ \\
\hline
\end{tabular}

Table 3: AP and SOD levels in control and experimentally Zn deficient lambs.

\begin{tabular}{|c|c|c|c|c|}
\hline \multirow{2}{*}{ Time } & \multicolumn{2}{|r|}{$\mathrm{AP}$} & \multicolumn{2}{|c|}{ SOD } \\
\hline & Control & Zn deficient lambs & Control & Zn deficient lambs \\
\hline 0 - days & $151.1 \pm 11.1$ & $146.1 \pm 10.2$ & $23.4 \pm 0.3$ & $24.4 \pm 0.7$ \\
\hline 2 weeks & $148.4 \pm 8$ & $132.7 \pm 9$ & $24.1 \pm 0.4$ & $22.2 \pm 0.4$ \\
\hline 4 weeks & $130.9 \pm 6.9$ & $128.1 \pm 9.1$ & $19.8 \pm 0.5$ & $20.1 \pm 0.6$ \\
\hline 6 weeks & $135.2 \pm 7.3$ & $131.5 \pm 6$ & $22 \pm 0.7$ & $19.6 \pm 0.7$ \\
\hline 8 weeks & $141.3 \pm 5.9$ & $136.2 \pm 8$ & $20.7 \pm 0.9$ & $19 \pm 0.6$ \\
\hline 10 weeks & $136.1 \pm 8.6$ & $91.7 \pm 4.3^{*}$ & $19.5 \pm 1.1$ & $16.5 \pm 0.5^{*}$ \\
\hline 12 weeks & $132.2 \pm 6.2$ & $65.3 \pm 3.6^{* *}$ & $22.8 \pm 0.5$ & $14 \pm 0.8 * *$ \\
\hline
\end{tabular}

Table 4: Correlations (r) between $\mathrm{Zn}$ concentrations in urine, serum, feces and ruminal juice in $\mathrm{Zn}$ deficient lambs.

\begin{tabular}{ccccc}
\hline & Urine & Serum & Feces & Ruminal juice \\
\hline Urine & - & $0.90^{* *}$ & $0.63^{*}$ & $0.80^{* *}$ \\
\hline Serum & $0.90^{* *}$ & - & $0.74 * *$ & $0.96^{* *}$ \\
\hline Feces & $0.63^{*}$ & $0.74 * *$ & - & $0.84^{* *}$ \\
\hline Ruminal juice & $0.80^{* *}$ & $0.80^{*}$ & $0.84^{* *}$ & - \\
\hline$* P<0.05 * * P<0.01$ & &
\end{tabular}




\section{DISCUSSION}

$\mathrm{Zn}$ is an essential trace element that is required by all cells in animals as well it plays a clear and effective roles in numerous enzymatic reactions, nevertheless deficiency of $\mathrm{Zn}$ are associated with reduced growth rate, poor immune function, decrease reproductive performance, as well as causing skin abnormalities. Decrease of appetite in $\mathrm{Zn}$ deficient lambs which represented by significant decrease in the ruminal movement may due to reduced ability to taste and smell foods (Droke et al., 1993a) whereby changes in appetite are associated with changes in the concentration of amino acid derived neurotransmitters in the brain, thus some trace elements deficiency as $\mathrm{Zn}$ may reduce the appetite by impairing the taste because it postulated that the sense of taste is mediated through the salivary $\mathrm{Zn}$ dependent therefore low salivary $\mathrm{Zn}$ concentration leads to a reduction of taste and reduced appetite. (Failla, 2003).

Reduced appetite has been also reported in buffalo calves affected with $\mathrm{Zn}$ deficiency (Al-Saad et al., 2006). As well as reduced appetite and ruminal movement can postulate the reduction in the body weight (Van Wouwe, 1989) and body weight gain in experimentally $\mathrm{Zn}$ deficient sheep in this study.

Alopecia was the second most frequent sign in sheep with $\mathrm{Zn}$ deficiency. This finding is in accordance with those of others in calves (Machen et al. (1996); Radostits et al. (2000); Sharma and Joshi (2005)) and buffalo calves (Al-Saad et al., 2006). Of all tissues, the skin has the third highest abundance of $\mathrm{Zn}$ in the body. In the skin, the $\mathrm{Zn}$ concentration is higher in the epidermis than in the dermis, owing to a $\mathrm{Zn}$ requirement for the active proliferation and differentiation of epidermal keratinocytes (Ogawa et al., 2016).

The respiratory and heart rates were significantly higher $(\mathrm{p}<0.05)$ in $\mathrm{Zn}$ deficient sheep than in normal control sheep. These could be due to the fact that $\mathrm{Zn}$ is a component of the enzyme carbonic anhydrase, which is located in the red blood cells and parietal cells of the stomach and is related to the transport of respiratory carbon dioxide and the secretion of hydrochloric acid by the gastric mucosa (Radostits et al., 2000) as well as carbonic anhydrases are metalloenzymes that catalyze the reversible interconversion of $\mathrm{CO}_{2}$ and $\mathrm{HCO}_{3}{ }^{-}$(Aggarwal et al., 2015), so $\mathrm{Zn}$ deficiency causing disturbances in carbonic anhydrases which can no longer performthe $\mathrm{CO}_{2}$ to $\mathrm{HCO}_{3}{ }^{-}$(Kimber and Pai, 2000) resulting in accumulation of carbonic acid and carbon dioxide which manifested clinically in the form of increased respiratory and heart rate.

Plasma $\mathrm{Zn}$ which represents, $0.2 \%$ of total body $\mathrm{Zn}$ content, was the most frequently measured biomarker of $\mathrm{Zn}$ status, thus enabling the most comprehensive analysis of this biomarker (Lowe et al., 2009). Although plasma $\mathrm{Zn}$ concentration responds to altered intake over short periods, the homeostatic mechanisms that act to maintain plasma $\mathrm{Zn}$ concentration within the physiologic range (namely, adaptive changes in efficiency of absorption and levels of endogenous excretion) may prevent high plasma concentrations from being sustained over a prolonged period (Lowe et al., 2009).

Plasma $\mathrm{Zn}$ concentration can fall in response to factors unrelated to $\mathrm{Zn}$ status or dietary $\mathrm{Zn}$ intake, including infection, inflammation, stress, or trauma. Conversely, tissue catabolism during starvation can release $\mathrm{Zn}$ into the circulation, causing a transient increase in circulating $\mathrm{Zn}$ levels (Hambidge et al., 1989). The reliability of plasma $\mathrm{Zn}$ concentration as a biomarker of $\mathrm{Zn}$ status is also dependent on the proper collection and storage of the sample, because adventitious $\mathrm{Zn}$ can easily be added to samples by environmental exposure and inappropriate handling of samples. Care must be taken to avoid contamination from the collection or storage vessel, hemolysis of the sample when $\mathrm{Zn}$ is released from the red blood cells into the plasma. The time between taking the sample and the separation of the plasma from the red blood cells can also be crucial (Lowe et al., 1998). Plasma $\mathrm{Zn}$ levels are not considered an accurate reflection of dietary $\mathrm{Zn}$ intake or status (Wood, 2000). Plasma $\mathrm{Zn}$ content is generally considered a poor measure of marginal $\mathrm{Zn}$ deficiency (King, 1990) while, urinary Zn excretion can provide useful information on $\mathrm{Zn}$ status in $\mathrm{Zn}$-supplemented individuals, but whether these reflect $\mathrm{Zn}$ status in depleted individuals is not certain. It is clear that there is an urgent need to develop new biomarkers of Zn status (Hooper et al., 2009). A significant decrease in urine $\mathrm{Zn}$ concentrations in this study is agreed with the results obtained by Wood (2000).

A significant positive correlation between plasma and urine $\mathrm{Zn}$ may indicate that inefficiently transportation of $\mathrm{Zn}$ to the tissues and that some of $\mathrm{Zn}$ is excreted in the form of small molecular weight collates in to the urine (Main et al., 1982) and this is postulated by Van Rij et al. (1979) who found that intravenous injection of $\mathrm{Zn}$ caused significant increase in urine $\mathrm{Zn}$ excretion by six folds, as well as $\mathrm{Zn}$ supplementations significantly increased serum $\mathrm{Zn}$ (Bicer et al., 2011) urinary excretion of Zn (Eskici et al., 2016).

The major change in obligatory Znlosses in response to various dietary $\mathrm{Zn}$ loads is achieved by altering endogenous fecal Zn losses (King and Keen, 1994). Endogenous fecal $\mathrm{Zn}$ is a major regulatory focal point of whole body $\mathrm{Zn}$ homeostasis (Wood, 2000) A significant positive correlation between plasma and fecal $\mathrm{Zn}$ this may be attributed to that $\mathrm{Zn}$ losses principally in feces (Pond et al., 1995) and this confirmed the results of our study where there was a 
significant positive correlations between plasma and fecal $\mathrm{Zn}$ as well as significant decrease in fecal $\mathrm{Zn}$ concentrations in experimentally $\mathrm{Zn}$ deficient lambs earlier than that of serum, urine and ruminal juice. So significant decrease in the fecal $\mathrm{Zn}$ in this study may indicate that absorption of $\mathrm{Zn}$ into the bloodstream does not occur from the ruminant fore-stomach; however, $\mathrm{Zn}$ uptake occurs in ruminal tissue (Wright et al., 2008). A significant decrease in the ruminal juice $\mathrm{Zn}$ concentrations in $\mathrm{Zn}$ deficient sheep may indicate that $\mathrm{Zn}$ was uptake by the ruminal tissue and it was not absorbed from the ruminant foresto-mach to the blood stream (Wright et al., 2008).

Because $\mathrm{Zn}$ has an important role in many enzymes whether changes in some of these enzyme activities might be a biomarker of $\mathrm{Zn}$ status (Prasad et al., 1978). AP is a $\mathrm{Zn}$ dependent enzyme and dietary $\mathrm{Zn}$ deficiency will impair its activity (Vergnes et al., 1992) Plasma AP appeared to show as possible $\mathrm{Zn}$ dependent biomarkers (Baer and King, 1984; Kawamura, 2016). Significant decrease in AP in this study with significant decrease in plasma $\mathrm{Zn}$ postulated that positive correlations between $\mathrm{Zn}$ and AP and this results were confirmed by (Naitana, 1984) as well as Nagalakshmi et al. (2009) who found that significant increase in the AP in $\mathrm{Zn}$ supplemented lambs.

SOD enzymes catalyze the dismutation of superoxide radical into hydrogen peroxide $\left(\mathrm{H}_{2} \mathrm{O}_{2}\right)$ and molecular oxygen $\left(\mathrm{O}_{2}\right)$ and consequently present an important defense mechanism against superoxide radical toxicity (Assady et al., 2011; Kim et al., 2000) and it contains $\mathrm{Cu} \backslash \mathrm{Zn}$ at its active site (Thomas, 2006). In this study significant decrease in SOD in Zn deficient lambs and this results are not agree with the results obtained from Esen Gursel and Tekeli (2009) who found that $\mathrm{Zn}$ deficiency increase SOD in rats due to $\mathrm{Zn}$ deficiency resulted in increased lipid peroxidation and consequently increased SOD as a compensatory action against excessive lipid peroxidation, while Aggarwal et al. (2015) concluded that dietry Zn oxide supplementation increased total SOD and improved the antioxidant capacity. As well as Paik et al. (1999) postulated that extracellular SOD activities are decreased in subjects with low serum $\mathrm{Zn}$ concentrations and suggest that extracellular SOD activity may be a functional indicator of $\mathrm{Zn}$ nutritional status.

\section{CONCLUSION}

From the obtained results of this study, we can conclude that, evaluation of $\mathrm{Zn}$ concentrations in different body fluids rather than blood serum can be used as diagnostic tool for diagnosis of $\mathrm{Zn}$ deficiency in lambs. Fecal $\mathrm{Zn}$ concentration can be used as a biomarker for early diagnosis of $\mathrm{Zn}$ deficiency in lambs.

\section{REFERENCES}

Aggarwal, M.; Chua, T.K.; Pinard, M.A.; Szebenyi, D.M. and McKenna, R. (2015): Carbon Dioxide "Trapped" in a beta-Carbonic Anhydrase. Biochemistry 54, 6631-6638.

Al-Saad, K.M.; Al-Sadi, H.I. and Abdul-Majeed, M.O. (2006): Clinical and pathological studies on naturally occurring zinc deficiency (hypozincemia) in buffalo calves. Proceedings of the 4th Scientific Conference of College of Veterinary Medicine, (SCCVM'06), University of Mosul, Mosul, Iraq, . pp:97-107.

Assady, M.; Farahnak, A.; Golestani, A. and Esharghian, M. (2011): Superoxide Dismutase (SOD) Enzyme Activity Assay in Fasciola spp. Parasites and Liver Tissue Extract. Iranian journal of parasitology 6, 17-22.

Baer, M.T. and King, J.C. (1984): Tissue zinc levels and zinc excretion during experimental zinc depletion in young men. Am J Clin Nutr 39, 556-570.

Bicer, M.; Akil, M.; Sivrikaya, A.; Kara, E.; Baltaci, A.K. and Mogulkoc, R. (2011): Effect of zinc supplementation on the distribution of various elements in the serum of diabetic rats subjected to an acute swimming exercise. Journal of physiology and biochemistry 67, 511-517.

Droke, E.A.; Spears, J.W.; Armstrong, J.D.; Kegley, E.B. and Simpson, R.B. (1993a): Dietary zinc affects serum concentrations of insulin and insulin-like growth factor I in growing lambs. J Nutr 123, 13-19.

Esen Gursel, F. and Tekeli, S.K. (2009): The effects of feeding with different levels of zinc and chromium on plasma thiobarbituric acid reactive substances and antioxidant enzymes in rats. Polish journal of veterinary sciences $12,35-39$.

Eskici, G.; Gunay, M.; Baltaci, A.K. and Mogulkoc, $R$. (2016): The effect of zinc supplementation on the urinary excretion of elements in female athletes. Pakistan journal of pharmaceutical sciences 29, 125-129.

Failla, M.L. (2003): Trace elements and host defense: recent advances and continuing challenges. J Nutr 133, 1443s-1447s

Fuwa, K.; Pablo, P. and Robert, M. and Vallee, B.L. (1964): Determination of Zinc in Biological Materials by Atomic Absorption Spectrometry. Anal Chem, 36, 2407-2411.

Hambidge, K.M.; Goodall, M.J.; Stall, C. and Pritts, J. (1989): Post-prandial and daily changes in plasma zinc. J Trace Elem Electrolytes Health Dis 3, 55-57.

Hooper, L.; Ashton, K.; Harvey, L.J.; Decsi, T. and Fairweather-Tait, S.J. (2009): Assessing potential biomarkers of micronutrient status by 
using a systematic review methodology: methods. Am J Clin Nutr 89, 1953s-1959s.

Kawamura, T. (2016): [The functional role of zinc in skin diseases]. Nihon Rinsho 74, 1144-1149.

Kim, T.S.; Jung, Y.; Na, B.K.; Kim, K.S. and Chung, P.R. (2000): Molecular cloning and expression of $\mathrm{Cu} / \mathrm{Zn}$-containing superoxide dismutase from Fasciola hepatica. Infection and immunity 68, 3941-3948.

Kimber, M.S. and Pai, E.F. (2000): The active site architecture of Pisum sativum beta-carbonic anhydrase is a mirror image of that of alphacarbonic anhydrases. Embo j 19, 1407-1418.

King, J. and Keen, C. (1994): Zinc. Shils, M. Olson, J. Shike, M. eds. Modern Nutrition in Health and Disease: 214-230 Lea \& Febiger Philadelphia, PA.

King, J.C. (1990): Assessment of zinc status. The Journal of nutrition 120 Suppl 11, 1474-1479.

Lowe, N.M.; Fekete, K. and Decsi, T. (2009): Methods of assessment of zinc status in humans: a systematic review. The American journal of clinical nutrition, ajcn. 27230G.

Lowe, N.M.; Woodhouse, L.R. and King, J.C. (1998): A comparison of the short-term kinetics of zinc metabolism in women during fasting and following a breakfast meal. Br J Nutr 80, 363370.

Machen, M.; Montgomery, T.; Holland, R.; Braselton, E.; Dunstan, R.; Brewer, G. and Yuzbasiyan-Gurkan, V. (1996): Bovine hereditary zinc deficiency: lethal trait A 46. J Vet Diagn Invest 8, 219-227.

Main, A.N.; Hall, M.J.; Russell, R.I.; Fell, G.S.; Mills, P.R. and Shenkin, A. (1982): Clinical experience of zinc supplementation during intravenous nutrition in Crohn's disease: value of serum and urine zinc measurements. Gut 23, 984-991.

Miller, J.K. (1967): Effect of protein source and feeding method on zinc absorption by calves. $\mathrm{J}$ Nutr 93, 386-392.

Nagalakshmi, D.; Dhanalakshmi, K. and Himabindu, D. (2009): Effect of dose and source of supplemental zinc on immune response and oxidative enzymes in lambs. Veterinary research communications 33, 631-644.

Naitana, S. (1984): [Correlation of blood zinc and alkaline phosphatase]. Bollettino della Societa italiana di biologia sperimentale 60, 519-521.

Nishikimi, M.; Roa, N.A. and Yogi, K. (1972): Occurrence of superoxide anion in the reaction of reduced phenazine methosulfate and molecular oxygen. Biochem Bioph Res Common 46, 849-854.

$N R C$ (1985): Nutrient requrmints of sheep. National research council,6th Ed National Academy press Wshington, DC.
Ogawa, Y.; Kawamura, T. and Shimada, S. (2016): Zinc and skin biology. Arch Biochem Biophys.

Paik, H.Y.; Joung, H.; Lee, J.Y.; K., H.; Lee, J.C. and King, C.L.K. (1999): Serum extracellular superoxide dismutase activity as an indicator of zinc status in humans. Biol Trace Elem Res 69.

Pond, W.G.; Church, D.C. and Pond, K.R. (1995): Basic animal nutrition and feeding 4th Ed., John Wiley and Sons, New York,. pp. 185224.

Prasad, A.S.; Rabbani, P.; Abbasii, A.; Bowersox, E. and Fox, M.R. (1978): Experimental zinc deficiency in humans. Annals of internal medicine 89, 483-490.

Radostits, O.M.; Gay, C.C. and Hinechliff, K.W. (2000): Veterinary medicine, A Textbook of the diseases of cattle, sheep, pigs, goat and horses. 9th ed W. B. Saunders Company Ltd., London, . pp. 1510-1533,1819-1822 .

REC.GSCC (DGKC) (1972): J.Clin.Chem. Biochem 10, 182.

SAS (2005): Analytic software. Student Edition of Statestics (Sxw), version 8.1. SAS Institute Inc, Cary, NC, USA.

Shankar, A.H. and Prasad, A.S. (1998): Zinc and immune function: the biological basis of altered resistance to infection. The American journal of clinical nutrition $68,447 \mathrm{~S}-463 \mathrm{~S}$.

Sharma, M.C. and Joshi, C. (2005): Therapeutic efficacy of zinc sulphate used in clustered model treatment in alleviating zinc deficiency in cattle and its effect on hormones, vitamins and production parameters. Vet Res Commun 29, 609-628.

Thomas, M.D. (2006): Textbook of biochemistry with clinical correlations. 6th. Ed. AJohn Wiley and sons, INC Publication.

Van Rij, A.M.; Godfrey, P.J. and McKenzie, J.M. (1979): Amino acid infusions and urinary zinc excretion. J Surg Res, 26: 293-299.

Van Wouwe, J.P. (1989): Clinical and laboratory diagnosis of acrodermatitis enteropathica. Eur J Pediatr 149, 2-8.

Vergnes, H.; Courdouhji, M.K.; Grozdea, J.; BrissonLougarre, A. and Guelfi, J.F. (1992): Effects of dietary zinc deficiency on plasma inorganic phosphorus, calcium and alkaline phosphatase in growing lambs. Small Ruminant Research 7, 35-42.

Wood, R.J. (2000): Assessment of marginal zinc status in humans. The Journal of nutrition 130, $1350 \mathrm{~s}-1354 \mathrm{~s}$.

Wright, C.L.; Spears, J.W. and Webb, K.E., Jr. (2008): Uptake of zinc from zinc sulfate and zinc proteinate by ovine ruminal and omasal epithelia. Journal of animal science 86, 13571363. 
علاقة تركيز الزنك في عصارة الكرش والبول ومصل الدم والبراز في الحملان الاوسيمي المصابه بنقص الزنك التجريبي

$$
\text { عبل الغتي حفناوي عبل الغتي ، محمود عاطف هلال ، ابراهير صبري ، بيسين عبل الرؤوف }
$$

E-mail: Abdelghany_hefnawy@yahoo.com Assiut University web-site: www.aun.edu.eg

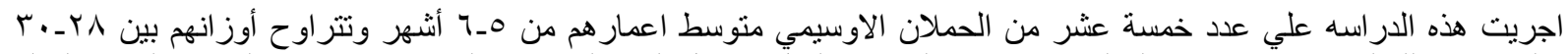

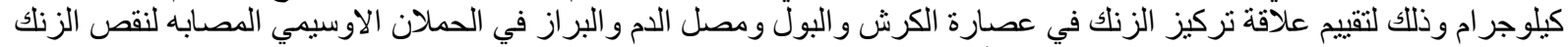

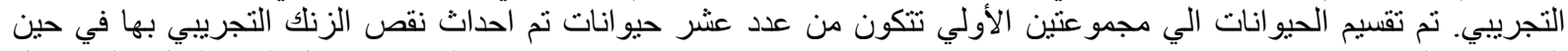

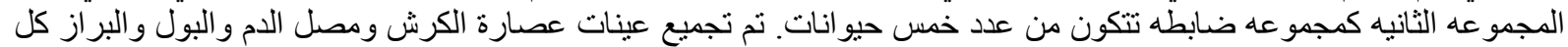

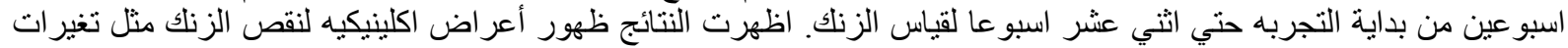

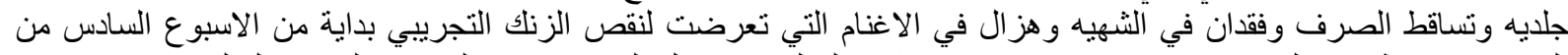

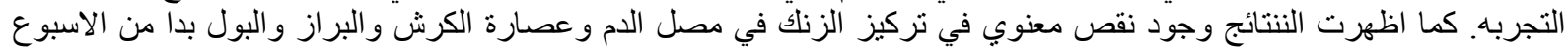

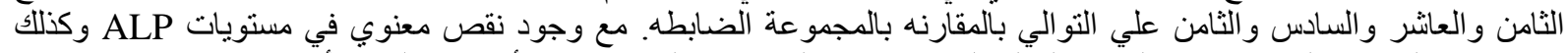

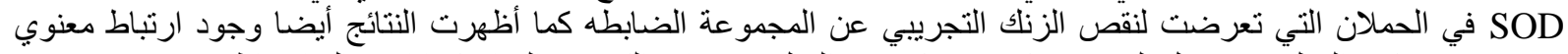

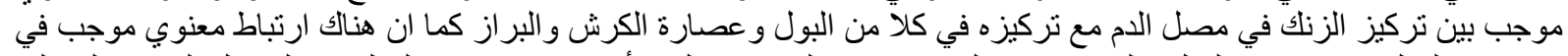

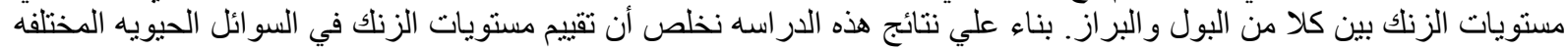

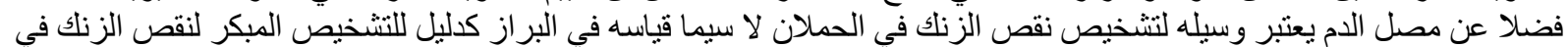

